\title{
Studies on Vegetative and Reproductive Ecology of Paris polyphylla Smith: A Vulnerable Medicinal Plant
}

\author{
Chitta Ranjan Deb*, Sakutemsu L. Jamir, Nangshimeren Sakutemsu Jamir \\ Department of Botany, Nagaland University, Lumami, India \\ Email: "debchitta@rediffmail.com, debchitta@gmail.com
}

Received 9 September 2015; accepted 18 October 2015; published 21 October 2015

Copyright (C) 2015 by authors and Scientific Research Publishing Inc.

This work is licensed under the Creative Commons Attribution International License (CC BY). http://creativecommons.org/licenses/by/4.0/

(c) $)$ (i) 0 pen Access

\begin{abstract}
Paris polyphylla Smith is an important medicinal plant that is considered vulnerable in many parts of the world. The species exhibits poor adaptability to changed environment and susceptible to climatic conditions for reproductive vigor. During the present study the species was studied in four different natural niches as well as synthetic habitats to check the adaptability to artificial conditions, its morphological and physiological characters and its interaction in its community so that conservation strategies could be worked out. The present study indicates that $P$. polyphylla exhibits healthy growth as well as reproduction in undisturbed area with canopy covers over $80 \%$. The plant grows in well-drained rich humus soil and grows well with certain key associated species such as Quercus species, Taxus baccata, Aconitum species, Eupatorium adenophorum, Smilax species etc. Many plants were non-flowering and more than $60 \%$ were found non-flowering in its habitat during its flowering season in any particular year. There are clear morphological changes as the flowers stages from pre-fertilization to post-fertilization. Arrangement of anthers in two whorls shows a distinct and unique floral display. Light is an important factor during seed setting and less than $50 \%$ shade lowers the seed productivity very significantly. Predators such as slugs and snails are found on the plant. Urgent conservation and new innovative ways are necessary to propagate this economically important plant to ensure its continuity.
\end{abstract}

\section{Keywords}

Associated Species, Floral Biology, Niche Characterization, Primary Habitat, Reproductive Biology

\section{Introduction}

Plant reproductive biology and phenological studies are important for understanding and knowing the plant in its ${ }^{*}$ Corresponding author.

How to cite this paper: Deb, C.R., Jamir, S.L. and Jamir, N.S. (2015) Studies on Vegetative and Reproductive Ecology of Paris polyphylla Smith: A Vulnerable Medicinal Plant. American Journal of Plant Sciences, 6, 2561-2568. 
various stages of its life cycle from the time of its sprouting till its senescence along with the various barriers associated the plant so that this knowledge helps in knowing how plants interact within its community and what actions can be done for the conservation of the plants [1]-[2]. The word "Paris" is derived from Latin word "pars" meaning equal often referring to the symmetry of the plant for its equal number of floral parts and leaves and the work "Polyphylla" refers to the many (poly) and leaves (phylla). Paris L. (Melanthiaceae) genus consists of about 24 species which is distributed from Europe to Asia [3]. Paris polyhylla is categorized as sparse [4] in India but it is listed under vulnerable category in Nepal [5]. Paris polyphylla is an important medicinal plant containing saponin steroids polyphyllin D, dioscin and balanitin 7 [6]. Rhizome of the plant is used as antihelmintic, antispasmodic, digestive stomachic, expectorant and vermafuge [5], scabies, rashes, or itching problems [7], to treat liver cancer [6]. The roots are also fed to cattle with diarrhea and dysentery [5].

In Nagaland, forests are lost or fragmented due to intensive "Slash and Burn" cultivation or "Jhum" cultivation, logging and developmental activities [8], incidences of forest fires along with large scale landslides effects and threaten the biodiversity of a forest. Plants which are at constant threat need immediate conservation. Paris polyphylla is under constant threat because of rampant harvesting for local medicine as well as illegal trade to the neighboring states like Manipur and countries like Myanmar [9]. The plant which was quite abundant in the last decade has decreased drastically and therefore conservation of this plant is highly important in the wild as well as educating the locals on the importance of this plant and its conservation in the state.

Plants with its certain morphological limitation factors like habitat specific, slow growth and time taken to become reproductively mature along with reproductive limitations such as non-reproductive plants and long term seed dormancy adds to the rapid reduction in its species. Thus studies on floral phenology, reproductive biology are very important for determining conservation strategies of such economically important threatened plant. Present study focuses on different aspects of habitat ecology, adaptability to artificial habitat, floral biology, reproductive biology and seed biology of Paris polyphylla.

\section{Materials and Methods}

Field collection and visits were conducted in selected four parts of Nagaland (India) where Paris polyphylla are found. The selected four areas were based on the abundance of the plant species through primary data from the locals, high gap ranges of elevation differences between the selected areas so as to check any differences on the plant species, vegetation type and landscape features and human role played on the selected forest area. The four areas are forest area of Pangsha village (Tuensang district) at an elevation of $2278 \mathrm{~m}$ (ASL), 26 $6^{\circ} 14^{\prime} 27.2^{\prime \prime} \mathrm{N}$ and 95 $07^{\prime} 05.7^{\prime \prime E}$, Chida and its surrounding area (Phek district) at an elevation of $1874 \mathrm{~m} \mathrm{ASL,} 25^{\circ} 30^{\prime} 11^{\prime \prime} \mathrm{N}$ and

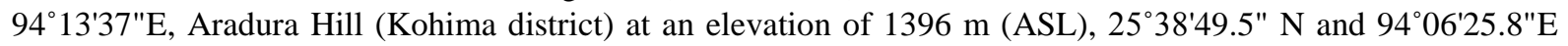
and Longkum village forest area (Mokokchung district) at an elevation of $1404.51 \mathrm{~m}$ (ASL), $29^{\circ} 15^{\prime} 98.8^{\prime \prime} \mathrm{N}$ and 94² $24^{\prime} 03.5^{\prime \prime}$.

Field visits conducted for this perennial herb for four years to monitor the plant formation, sprouting of shoots till its senescence. Morphological aspects of the plants, their phenology and reproductive biology were studied. Along with this, characteristics ecology of the plant, its associated species, canopy cover, level of anthropogenic disturbances were studied.

Adaptability of the plant species outside its natural habitat was studied through establishment in artificial habitat at Penli ward (Mokokchung) at $1259 \mathrm{~m}$ (ASl) where the plants collected from the four studied areas were kept in different potting mixture at different shaded conditions:

1) Manure soil by mixing decayed wood, sand and top black soil at a ratio of 1:1:3.

2) Mixture of cow dung, sand and top black soil at a ratio of 1:1:3.

3) Only to black soil.

Plants were monitored constantly for its growth and development. Changes in the soil were done every year to ensure nutrient availability to the plants.

The experimental beds were provided with different shaded conditions as below:

a) Zero shade.

b) Plants kept in association with domestic garden plants and climbers which provides partial shade.

c) Plants kept in polyhouse ca. $75 \%$ shade.

Plants grown in different soil mixture, their adaptation outside the natural habitats, effect of temperature and shaded conditions on the plant growth and development were studied. 


\section{Results}

\subsection{Habitat}

Paris polyphylla is an important medicinal perennial plant. The present investigation study was conducted in 4 natural habitats with a total of 8 populations for 4 years. Plants usually grow inside deep forest where human interference is minimal and under shade (Table 1, Figure 1(a)). But with increase in disturbance level the population was found to become thinner. Paris is a shade loving plants and grows under the canopy closure of more than $80 \%$ at an altitude of 1300 - 2500 m ASL in Sub-tropical broad leaved hill forest to moist temperate broad leaf forest. It grows in moist and well-drained soil and usually on slope areas with north facing with soils that are usually covered with dry and decay organic matters. The plants are erect herbs growing up to a meter tall (Figure 1(b)). Plants that lack inflorescence are usually shorter in height. The plants grow well in well-drained humus soil and water logging is lethal to this group of plants.

Of the four sites studied during the present investigation, high level of disturbances was found in the unprotected forest area of Pangsha area while village protected forest areas like in Longkhum forest area and Chida area shows limited disturbances (Table 1). These disturbances are not due to deforestation or any other anthropogenic activities but due to over-exploitation of $P$. polyphylla rhizome for local medicinal use as well as illegal exports outside the state. Paris polyphylla found in and around the area of Chida (Khezakenoma) area were found growing the best in slope areas with well-drainage and the plants were found growing for even more than $1 \mathrm{~m}$ in this area (Figure $\mathbf{1}(\mathrm{c})$ ).

Besides the natural habitats, plants were also rehabilitated in artificial habitats with similar altitudes and temperatures. It was found that in these artificial habitats though plants grew normally in the first year, failed to flower. In some cases wherever they flowered, failed to form fruit and seed setting and degenerated subsequently.

During the present study it was observed that in all the study areas, there were some common associated species (Table 2). Healthy growth of P. polyphylla was observed wherever these associated species were present

Table 1. Niche characterization of Paris polyphylla in Nagaland.

\begin{tabular}{|c|c|c|c|c|}
\hline Site name & Locality & Elevation & $\begin{array}{l}\text { Canopy } \\
\text { Closure }\end{array}$ & Disturbances \\
\hline Tuensang & Pangsha area & $2278 \mathrm{~m}$ ASL $\left(26^{\circ} 14^{\prime} 27.2^{\prime \prime} \mathrm{N}\right.$ and $\left.95^{\circ} 07^{\prime} 05.7^{\prime \prime E}\right)$ & $86 \%$ & High human interference \\
\hline Phek & $\begin{array}{c}\text { Chida and its } \\
\text { surrounding area }\end{array}$ & 1874 m ASL (25³0'11"N and 94¹3'37"E) & $88 \%$ & Limited human interference \\
\hline Kohima & Aradura hill & 1490 m ASL, $\left(26^{\circ} 14^{\prime} 27.2^{\prime \prime} \mathrm{N}\right.$ and $\left.95^{\circ} 07^{\prime} 05.7^{\prime \prime E}\right)$ & $84 \%$ & Protected area \\
\hline Mokokchung & Longkum village & $1404.51 \mathrm{~m}$ ASL $\left(29^{\circ} 15^{\prime} 988^{\prime \prime N}\right.$ and $\left.094^{\circ} 24^{\prime} 035^{\prime \prime E}\right)$ & $87 \%$ & Limited human interference \\
\hline
\end{tabular}

Table 2. Associated herbaceous plants found near Paris polyphylla.

\begin{tabular}{ccc}
\hline Sl. No. & Plant species & Family \\
\hline 1. & Ageratum conyzoides & Asteraceae \\
2. & Bidens pilosa & Euphorbiaceae \\
3. & Breynia sp. & Hypoxidaceae \\
4. & Curculigo capitulata & Dioscoreaceae \\
5. & Dioscorea sp. & Schrophulariaceae \\
6. & Drymeria cordata & Asteraceae \\
7. & Eupatorium adenophorum & Solygonaceae \\
8. & Fagopyrum esculentum & Lycopodiaceae \\
10. & Hottuynia cordata & Smilaceae \\
11. & Lycopodium sp. & Asteraceae
\end{tabular}

Note: The above table gives generalized common plants which are found within $5 \mathrm{~m}$ perimeter where Paris polyphylla is found in its natural habitat. 


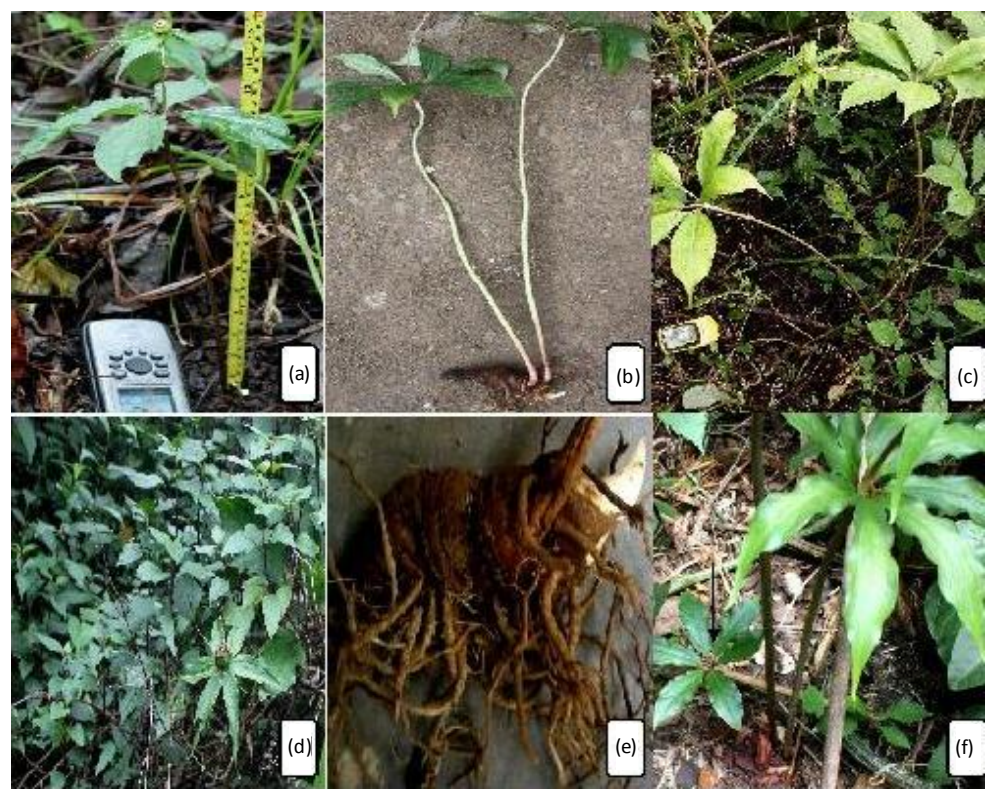

Figure 1. (a) Paris polyphylla growing in the natural habitat; (b) P. polyphylla plants with rhizome; (c) over $1 \mathrm{~m}$ tall plants growing in Chida village (at higher altitude); (d) common associated species growing with $P$. polyphylla in natural habitat; (e) a P. polyphylla rhizome; (f) sprouting of new shoots from rhizome in the mid season resulted in non-flowering plants.

within $5 \mathrm{~m}$ perimeter compared to the areas where these species were absent. Some of the common associated species identified in all the niches are: Trees-Schima wallichi, Alnus nepalensis, Bauhinia Purpurea, Albizia Procera, Pinus Roxburghii, Rhodedendrons arboreus, Quercus sps. Taxus Baccata, Bamboos; Herbs-Berberis sps, Aconitium sps , Impatiens sps, Ageratum conyzoides, Bidens pilosa, Curculigo capitulata, Dioscorea species, Drymeria cordata, Eupatorium adenophorum, Fagopyrum esculentum, Hottuynia cordata, Spilanthes acmella, Lycopodium sps. Ferns, Bryophytes; Climbers-Smilax species (Figure 1(d)).

\subsection{Rhizome Characteristics}

Paris polyphylla rhizomes are horizontal and creeping with transverse rings/bud scale scars on its rhizome (Figure 1(e)). One ring or bud scale scar are added usually every year from the senescence of the above ground part during late autumn and therefore one can determine the age of the plant by simply counting the rings but sometimes a plant can give rise to compound bud, therefore counting the age of the plant by the rings/bud scale scars is inapplicable and not accurate. Further it was found that in some cases a rhizome which already has a matured flowering plant gives rise to new buds in the middle of the year usually during the month of April and May (Figure 1(f)).

\subsection{Phenology and Reproductive Biology of P. polyphylla}

The degree of plant survival is related to its reproductive output and success. Therefore, considering this, $P$. polyphylla plants were carefully studied and tagged to see their inflorescence development and non-development in the studied plant population. The method applied was simple and traditional. Plants in a given population during the March and April were counted and tagged as reproductive (flowering) and non-reproductive (nonflowering) (Figure 2(a)). The bud in Paris polyphylla remains dormant for 4 - 5 months during the winter season until the next sprouting season. Paris polyphylla starts sprouting from February onwards till the month of March gives rise to new above ground stems, leaves and inflorescence. Majority of the plants found all the natural habitats and also grown under controlled conditions were found to be non-reproductive or in other words absence of inflorescence. Over $60 \%$ of the studied plants were found to be non-reproductive (Table 3). During the sprouting of the above ground plant body, the leaves and the inflorescence usually develops synchronously 
Table 3. Percentage of non-reproductive Paris polyphylla plants.

\begin{tabular}{cccc}
\hline Location & $\begin{array}{c}\text { Total number of } \\
\text { plants observed }\end{array}$ & $\begin{array}{c}\text { Non-reproductive } \\
\text { plants }\end{array}$ & $\begin{array}{c}\text { \% non-reproductive } \\
\text { plants }\end{array}$ \\
\hline Tuensang & 732 & 453 & 61.88 \\
Phek & 602 & 318 & 52.82 \\
Kohima & 167 & 113 & 67.66 \\
Mokokchung & 244 & 152 & 62.29 \\
Total & $\mathbf{1 7 4 5}$ & $\mathbf{1 0 3 6}$ & $\mathbf{6 1 . 1 6}$ \\
\hline
\end{tabular}

Note: Plants were studied in different locations within the whole district; non-flowered plants were very high in Paris polyphylla plants and it accounted for more than $60 \%$ in total plant populations.

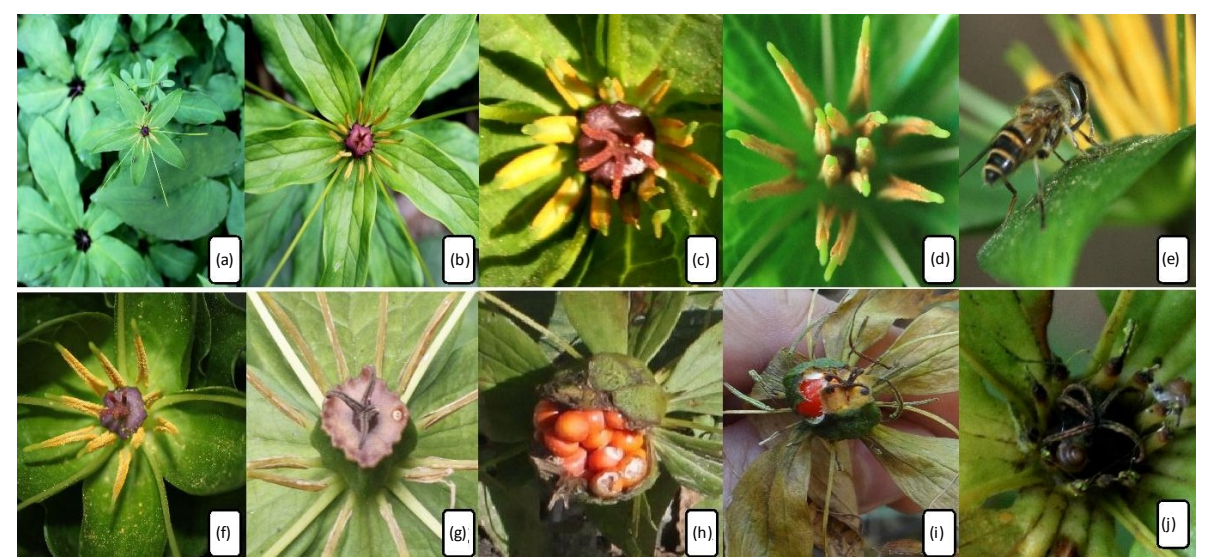

Figure 2. (a) Development of flowering and non-flowering plants in the same cluster; (b) solitary flower of $P$. polyphylla; (c) a flower showing roundish ovary with stigmatic lobes; (d) anthers of $P$. polyphylla arranged in 2 whorls; (e) a common pollinator engaged in pollination; (f) dispersal of pollens on the other parts of flowers; (g) post fertilization of modification of ovary (ovary turned dull purple); (h) mature fruit showing red seeds; (i) fruit with fewer seeds from plants growing under higher light intensity; (j) predator on the plant causing death to enlarging ovary.

and therefore non-reproductive plants are easily identified when the inflorescence lacks in P. polyphylla. The non-reproductive plants are independent in relation to the age of its rhizome in all matured plants. Plants which are non-reproductive can remain the same in the next season or becomes reproductive which is vice-versa for reproductive plants.

In P. polyphylla which bears inflorescence, flowering begins in March-April where the flowers bloom at the terminal and they are solitary (Figure 2(b)). At the initial growth, the inflorescence forms a closed whorl covered by the sepals enclosing the tepals, the anthers and the stigma. The ovary is roundish in shape situated in the middle with usually 5 stigmatic lobes which is wet type in nature (Figure 2(c)). Usually the stigma appears deep purple in color during the pollination period. In Paris polyphylla, the male function first than the female, therefore the flowers are protrandous. Flowers are perfect flowers as they contain both the male and female gametes within the same flower. Outer tepals are leafy and green, while the inner tepals are yellowish green and filiform. (Usually the numbers of outer and inner tepals are same). The number of stamens is usually more than double that of outer tepals. The anther displays a unique character. In P. polyphylla, the anther occurs in two whorls (Figure 2(d)). Closing and opening of the anthers take place. Usually the outer whorl has two additional anther filaments compare to inner whorl. The inner whorl of the anther filament lies in between the two outer anther filaments. However, in the flower there will be two outer anther filaments on adjoining side that has one inner anther whorl filament within them. This anther display is same in many flowers of Paris polyphylla. Stigma is wet and the stigma lobes are usually 4 or 5 and re-curved at the tips. Plants generally remain at bloom for a period of 2 - 3 weeks. The timing of anthesis is between 6:30 - 7:30 A.M. and the anther dehisces by 7:30 - 8:30 A. 
M. The timing of anther dehiscence of $P$. poyphylla varies even within the same individual species population in a particular area. Variation in difference of timing can be even up to 2 - 3 weeks. Usually the flowers are self pollinated. However chances of pollination can occur by small insects. The plants are visited by different insects such as different types of flies and bees especially during the middle of daytime from 11:00 A.M. till 3:00 P.M. (Figure 2(e), Table 4). These agents might help pollination indirectly. The buzzing of their wings of the insect flies especially bees might facilitate the pollen dispersal to the stigma within the flower itself or even to the surrounding flowers as the pollens are very light. However loss of large amount of pollens occurs within the plant. Since the pollen grains are very light, wind also acts as a pollinating agent. The plants are self compatible and they produce large amount of pollens. Huge amount of pollens are wasted which is indicated by the falling of pollens all over the outer tepals (Figure 2(f)). Stigmatic lobes are usually bright purple but turns dull purple once the pollination takes place. After pollination, the anthers shriveled up and the ovary color also changes from bright purple to dull purple which finally fades away. After fertilization, the ovary enlarges forming a globular capsule (Figure 2(g)). The anther, the filaments and the tepals slowly disintegrates off from the end towards the inflorescence. It was observed that a significant per cent of $P$. polyphylla though successful in yielding inflorescence and flowers (considered as fertile plants) failed to produce seeds.

\subsection{Fruiting and Seed Formation}

In P. polyphylla viable seed formation is very low and climatic factors play an important role. The fruit of Paris polyphylla which is a globular capsule bears the seeds inside them. The seeds are reddish orange in color and

Table 4. Reproductive phenology of Paris polyphylla.

\begin{tabular}{|c|c|}
\hline Parameters & Observations \\
\hline Height of the plant & Up to $1 \mathrm{~m}$ \\
\hline Rhizome type & Horizontal and creeping \\
\hline Sprouting of plant from rhizome & February-March \\
\hline Dormancy of rhizome & 4- 5 Months \\
\hline Leaves & Lanceolate or sometimes oblong \\
\hline Outer tepals & Leafy green \\
\hline Inner tepals & Yellowish green and filiform \\
\hline Flowering & March-April \\
\hline Flowers & Solitary and terminal \\
\hline Time of anthesis & $6: 30-7: 30$ AM \\
\hline Time of anther dehiscence & 7:30 - 8:30 AM \\
\hline Stigma & Wet type \\
\hline Stigma lobes & (4) or 5 \\
\hline Pollination & Self-pollination \\
\hline Capsule before and during pollination & Bright and deep purple \\
\hline Capsule after pollination & Dull purple \\
\hline Fruiting & May \\
\hline Temperature for seed production & $18^{\circ} \mathrm{C}-23^{\circ} \mathrm{C}$ \\
\hline seed & Reddish orange color \\
\hline Seed maturation & September-October \\
\hline Dispersal of seeds & Gravity \\
\hline Senescence & October-November \\
\hline
\end{tabular}


when the fruit matures (Figure 2(h)). It was observed that the seed production is affected by the sunlight and heat. During the development phase, if the plants are exposed to direct sunlight, the seed production is very low. If the plants are maintained under $<80 \%$ shade compare to normal day light seed production is affected, but if again the shade cover is less than $50 \%$, than either the fruits are seedless or will have very few seeds (Figure 2(i)). It can be at times as few as 1 - 2 seeded fruits. Generally seeds are produce in large quantity in well-suited plant habitats. The outer covering of the capsule slits open exposing the seeds. The occurrence of a slit on the side of the globular capsule fruit indicates the enlargement of fruits and its maturity. The seeds are dispersed by gravity and dispersal is localized in and around the mother plant. Seeds do not germinate during the first year after its dispersal but stays dormant.

\subsection{Paris polyphylla Susceptibility to Climatic Conditions and Predators}

Plants are highly competitive with other herbaceous plants but at the same time they were found to be susceptible to the attack by various predators. In most of the habitats it was observed that snails and slugs were the predators of the fruits and the presence of them causes the death of the enlarging ovary (Figure 2(j)). Besides the biological agents, the plants are highly sensitive to the heat and sun light. Prolonged exposure to light and heat causes the plant to droop down and later dies off. Moisture content in the soil was also found to be very crucial for the growth of the plant and water retention in the soil causes the rotting of the stem base of the plant as well as rotting of rhizomes.

\section{Discussion}

Paris polyphylla is an important perennial medicinal plant of North East India in general and Nagaland in particular. The plant species is widely distributed in the high altitude areas across the state but its population is decreasing at an alarming rate. At present the populations are scattered in some small patches. The main dispersal agent is gravity and the young plantlets are found in and around the mother plants. This factor also contributes to loss of the plant species. This is because the local medicine men, illegal harvesters collect the rhizomes from the natural populations as there is no commercial cultivation of the species. Random collection of plants without taking into consideration the flowering and non-flowering plants and uprooting the rhizomes without taking care of the younger plants which sprouted from either from seeds or fragmented rhizomes is one of the key factors for downsizing the population of $P$. polyphylla. But on the positive note, the loss of huge amount of pollens from plants can be dispersed easily among the plants within this population groups. Thus conservation of the species is very important and the first step is identifying and understanding the habitat of the plant. In order to locate the species whose population is very thin, knowledge of the associated species is very important to locate the species of interest whose population otherwise is very difficult to locate. There are very reports available on this approach of population inventory of RET species. Madhu et al. [5] used Artisaema species for determining the presence or absence of $P$. polyphylla in Nepal while Langhu and Deb [10] successfully used the associated species for locating Aconitum nagarum in Nagaland from various habitats. In the present study, this approach was found to very helpful for locating the Paris polyphylla population. Besides this, the information on associated species could be important tools for characterization of the niches for the species, rehabilitation of the threatened species from conservation view point. There might be a possibility that wherever the associated species are growing, the key species is absent. This could be due to sweeping species from that area due to various anthropogenic activities, but could be a place where the key species may be introduced for propagation and or conservation.

During the present study it was found that there was great amount of variations/polymorphism in phenology of the plants. From literatures available, it reflects that the polymorphism in the genus Paris is universal. According to Zhang et al. [3] P. polyphylla var. yunnanensis also exhibits phenotypic diversity which correlates with the morphological diversity of $P$. polyphylla found in Nagaland as in the present study.

It was found that anthers are arranged in two whorls and large numbers of pollens are wasted. Presence of large number of anthers and wastage of large number of pollens indicates that the species is not efficient in energy economy. In Paris polyphylla var. yunnanensis also reported the anthers are arranged in two whorls where they also studied the closing and opening of anthers [11]. According to them conservation of pollens in the flowers and enhanced the male fitness by its closing during night and during rains which was not observed in the present study. However, the occurrence of large amount of pollen waste during pollination might give heavy 
loss and expenditure of the plant energy, which shows plants poor effective mechanism in pollen dispersal to the stigma of the flower.

In Paris polyphylla var. yunnanensis it was found that fly was the main pollinating agent [11] which is in agreement with the present study. In addition, in the present study bees were also acting as pollinators. Seed production is very important for sexually reproduced plants for new generations. In $P$. polyphylla seeds are produced during warm weather usually mid-summer but if the plants are exposed to direct sunlight, aborts the seed or seed production is affected significantly. As the plant are shade loving, drooping of the plants usually occurs if they are exposed to direct sunlight even for 1 - 2 hours indicates that for good reproductive output the commercial growers should ensure proper care especially during flowering and seed setting.

\section{Conclusion}

Paris polyphylla is an economically important medicinal plant and the species is under severe threat. The findings of the present study provide us a clear picture about the natural habitat and their primary requirements for survival, flowering, fruiting, seed setting. Further the findings pinpoint why the species cannot be cultivated easily away from the natural habitat. The findings from the seed biology study will help the commercial growers for seed propagation of the seed. The local authority, government agency should join hands to develop Paris park/garden in the natural habitats to propagate and conserve this economically important species.

\section{Acknowledgements}

This work is financially supported by the Department of Biotechnology, Ministry of Science and Technology, Govt. of India, New Delhi, India through a research grant No. BT/ENV/BC/01/2010 to Prof. Chitta Ranjan Deb.

\section{References}

[1] Fenner, M. (1998) The Phenology of Growth and Reproduction in Plants. Perspectives in Plant Ecology, Evolution and Systematics, 1, 78-91. http://dx.doi.org/10.1078/1433-8319-00053

[2] Tandon, R., Shivana, K.R. and Mohan Ram, H.Y. (2003) Reproductive Biology of Butea monosperma (Fabaceae). Annals of Botany, 92, 715-723. http://dx.doi.org/10.1093/aob/mcg193

[3] Zhang, J., Wang, Y., Zhang, J., Ding, Y., Yu, H. and Jin, H. (2011) Evaluation of Mineral Element Contents in Paris polyphylla var. yunnanensis from Southwest China. African Journal of Pharmacy and Pharmacology, 5, 1792-1796. http://dx.doi.org/10.5897/AJPP11.433

[4] Yonzone, R., Bhujel, R.B. and Rai, S. (2012) Genetic Resources, Current Ecological Status and Altitude Wise Distribution of Medicinal Plants Diversity of Darjeeling Himalaya of West Bengal, India. Asian Pacific Journal of Tropical Biomedicine, 12, S439-S445. http://dx.doi.org/10.1016/s2221-1691(12)60203-2

[5] Madhu, K.C., Phoboo, S. and Jha, P.K. (2010) Ecological Study of Paris polyphylla Sm. Ecoprint, 17, 87-93.

[6] Li, F., Jiao, P., Yao, S., Sang, H., Qin, S., Zhang, W., Zhang, Y. and Gao, L. (2012) Paris polyphylla Smith Extract Induces Apoptosis and Activates Cancer Suppressor Gene Connexin26 Expression. Asian Pacific Journal of Cancer Prevention, 13, 205-209. http://dx.doi.org/10.7314/APJCP.2012.13.1.205

[7] Jamir, N.S., Lanusunep and Pongener, N. (2012) Medico-Herbal Medicine Practiced by the Naga Tribes in the State of Nagaland (India). Indian Journal of Fundamental and Applied Life Sciences, 2, 328-333.

[8] Reddy, C.S., Dutta, K. and Jha, C.S. (2013) Analysing the Gross and Net Deforestation Rates in India. Current Science, 105, 1492-1500.

[9] Mao, A.A., Hynniewta, T.M. and Sanjappa, M. (2009) Plant Wealth of Northeast India with Reference to Ethnobotany. Indian Journal of Traditional Knowledge, 8, 96-103.

[10] Langhu, T. and Deb, C.R. (2014) Studies on the Reproductive Biology and Seed Biology of Aconitum nagarum Stapf: A Threatened Medicinal Plant of North East India. Journal of Research in Biology, 4, 1465-1474.

[11] Dingkang, W., Guifang, S., Lifang, W., Shuhua, Z. and Xiaojiang, C. (2009) A Novel Mechanism Controls Anther Opening and Closing in Paris polyphylla var. yunnanensis. Chinese Science Bulletin, 54, 244-248. http://dx.doi.org/10.1007/s11434-008-0507-y 